\title{
FROM THE INTRODUCTION
}

When Gina was deported to Tijuana, Mexico, in 2011, she was scared. Although she was born in Mexico, her only memory of being there was a fuzzy, dreamlike recollection of falling off a burro-a donkey-when she was three or four years old. Her parents brought her to the United States when she was young; she's not sure how old she was. She knows she was born in Guerrero, one of Mexico's poorest states. After explaining this, she quickly says, "Don't ask me more because I don't know." Her childhood memories revolve around her life in the U.S.--going to school, attending birthday parties at Chuck E. Cheese, and dancing at her high school prom. As an adult, she gave birth to three children in the U.S. and celebrated countless holidays with her parents and siblings, all now U.S. citizens. . . .

Following her deportation, she was alone in Tijuana-separated from her children and all of her earthly possessions. Everything felt foreign and intimidating. She explains, "I got scared when I first got in to TJ [Tijuana]. I was in shock." . . .

Six years after her deportation to Mexico, Gina still misses home. "I miss everything about it," she explains, "my kids, my family, the food, the places, the clothes, the jobs. Everything. This is not what I'm used to." 
This page intentionally left blank 


\section{DEPORTED AMERICANS}


This page intentionally left blank 


\section{DEPORTED AMERICANS}

Life after deportation to mexico beth C. CaldWell 


\section{() 2019 DUKE UNIVERSITY PRESS ALL RIGHTS RESERVED}

Printed in the United States of America on acid-free paper $\infty$ Designed by Courtney Leigh Baker and typeset in Knockout and Whitman by Westchester Publishing Services

Library of Congress Cataloging-in-Publication Data Names: Caldwell, Beth C., [date] author.

Title: Deported Americans : life after deportation to Mexico / Beth C. Caldwell.

Description: Durham : Duke University Press, 2019. |

Includes bibliographical references and index.

Identifiers: LCCN 2018037350 (print)

LCCN 2018049803 (ebook)

ISBN 9781478004523 (ebook)

ISBN 9781478003601 (hardcover : alk. paper)

ISBN 9781478003908 (pbk. : alk. paper)

Subjects: LCSH: Immigrant children-Legal status, laws, etc.

—United States. | Children of illegal aliens_-Legal status, laws, etc.

-United States. | Illegal alien children-Legal status, laws, etc.

-United States. | Mexicans_Legal status, laws, etc.-United States.

| Emigration and immigration law-United States. | Emigration and immigration law-Mexico. | Deportees-Family relationships.

| Deported children-Mexico. | Deportation-Social aspects.

Classification: LCC KF4848.M48 (ebook)|

LCC KF4848.M48 C35 2019 (print) | DDC 305.9/o691-dc23

LC record available at https://lccn.loc.gov/2018037350

COVER ART: Families separated by the two countries chat along the U.S.Mexico border fence at Border Field State Park, California, U.S., November 19, 2016. ReUters/Mike Blake. 
TO MOM AND DAD,

Thank you for your unconditional love, support, and generosity 
This page intentionally left blank 